まず、DOCの変化では対数増殖期中には著しい増加はなく、安定期に入ると培養時間とともに増加し、死堿 期に入るとほぼ一定となる傾向を示した。

P. tenueについては、DOCは対数増殖期中に著しく增加することなく、安定期に入ると培盖時間とともに 増加し、死隇期に入って培養41日目になるとほほ一定となる傾向を示した。各増殖期におけるDOCの見かけ 排出速度を求めると、対数増殖期では $0.012 \mathrm{mgC} / 1 /$ dayとしてほぼ排出が見られなかったが、安定期には 0 $.387 \mathrm{mgC} / 1 /$ dayとなった。死滅期には再び見かけ排出速度は $0.239 \mathrm{mgC} / 1 / \mathrm{day}$ と小さくなった。各增殖相に おける溶存有機炭素の見かけ排出速度をその平均現存量(POC)で割ることにより比排出速度 (mgDOC/mgPOC/ day)を求めると、安定期が $0.093 \mathrm{mgDOC} / \mathrm{mgPOC} /$ dayと最も高く、次に死滅期で $0.06 \mathrm{mgDOC} / \mathrm{mgPOC} / \mathrm{day}$ 、対数 増殖期には $0.013 \mathrm{mgDOC} / \mathrm{mgPOC} /$ dayの順となる。年. macrosporaについては、培責10日目まではDOC量は緩や かに増加し、その後、10日を過ぎるとDOCの見かけ排出速度が増加した。しかしながら、14日目以降はDOC の排出はほとんどみられなかった。DOCの見かけ排出速度 (mgC/ $/ /$ day)は、対数増殖期、安定期、死堿期に ついてそれぞれ 0.145、0.550、0.040 mgDOC/1/dayと安定期が最も高くなった。比排出速度 (mgDOC/mgPOC /day)を求めると、対数增殖期、安定期、死喴期についてそれぞれ $0.048 、 0.078 、 0.012 \mathrm{mgDOC} / \mathrm{mgPOC} / \mathrm{day}$ となり、安定期に最も多く代謝産物が排出されることが分かる。DOC中の各成分に注目すると、 $\underline{\text { P. tenue }}$ については対数増殖期には全糖類を主に排出するが、安定期以降はそれに加えてタンパク質を排出するよ うになる。DOC中の全糖類成分の割合は対数増殖期、安定期、死堿期に各々38.6、43.5、44.1\%として全 培養期間中にほほ $40 \%$ 程度を占める反面、タンパク質成分の割合は各々0.5、5.3、7.9\%として培養時間と ともに増加した。杰. macrosporaの対数增殖期の全糖類、タンパク質の見かけ排出速度を見ると、それぞれ、 $0.065 \mathrm{mgC} / 1 /$ day $0.119 \mathrm{mgC} / 1 /$ dayであるが、安定期には全糖類、タンパク質の見かけ排出速度は 0.299 $\mathrm{mgC} / \mathrm{l} / \mathrm{day} 、 0.141 \mathrm{mgC} / \mathrm{l} /$ dayとなり、対数増殖期と比べて全糖類の見かけ排出速度が増大している。測定 したDOC中の各成分に注目すると、全糖類成分の割合が対数增殖期、安定期、死减期に各々 57.7、55.3、 $59.3 \%$ として安定期以後に若干増加する。タンパク質成分の割合は各々 $15.3 、 25.7 、 26.6 \%$ として全糖類 の変化と同じ挙動を示した。

(B)暗条件における藻類の分解及び代謝産物の排出特性:

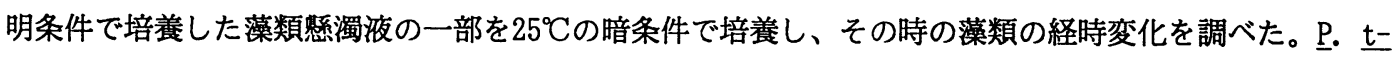
enueを供試藻類としたFig. 6では、Chl.a、SSとも緩やかに減少するのに対して細胞数が急激に隇少してい る。細胞数から求めた減少速度は $0.13 \mathrm{day}^{-1}$ であるのに対して、Chl.aより求めた減少速度は、0.016 $\mathrm{day}^{-1}$ である。これは活性を失つた藻類細胞の破片にもChl.a の成分が酸化せずに残存していることによるもの と思われる。またChl.a、SSの変化には目だった相異は見られなかったものの、細胞数の減少速度に比べる とほほ10倍も低くなり、Chl.a、SSの変化は必ずしも細胞数の変動によるものでないことがわかる。

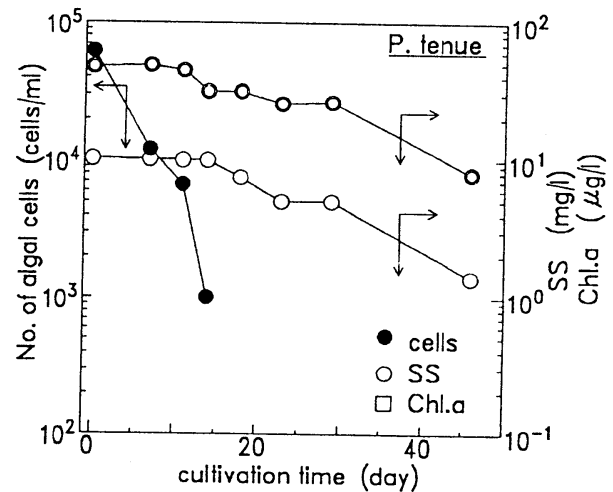

Fig. 6 Variation of algal cells, Chl.a and $S S$ by $P$. tenue under dark condition

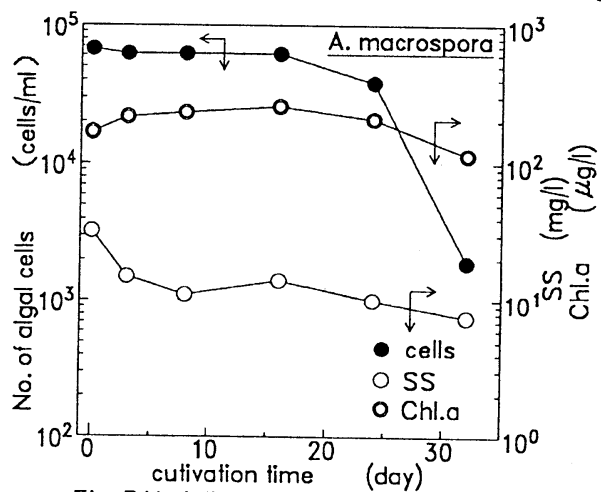

Fig. 7 Variation of algal cells, Chl.a and SS by $\mathrm{A}$. macrospora under dark condition 
Fig.7に明条件でA. macrosporaを11日まで培養した藻類䝮濁液の一部を $25^{\circ} \mathrm{C}$ 暗条件で培養し、その時の 藻類の経時変化を示す。 A. macrosporaは明条件から暗条件に移した後も約15日間、初期の細胞数を維持し、

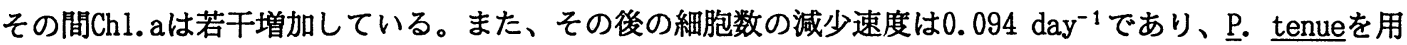
いた実験結果と比べると約1.5倍程度低く、吕 macrosporaの方がP. tenueより長期間活性を保ち、分解さ れにくいことが分かる。

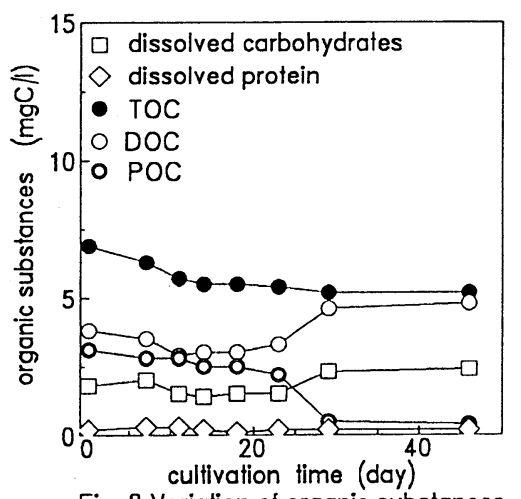

Fig. 8 Variation of organic substances by $P$. tenue under dark condition

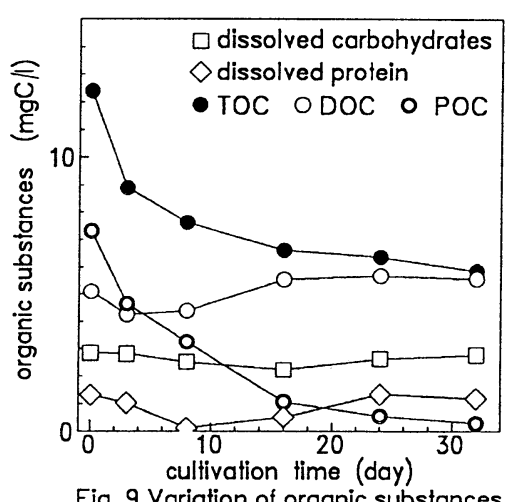

Fig. 9 Variation of organic substances by $\mathrm{A}$. macrospora under dark condition

次に暗実験より得られた代謝産物の経時変化をFig. 8、Fig. 9に示す。明条件から暗条件に移した直後は どの系においても DOC濃度がわずかに減少しているものの、10日以内に増加に転じ、以後DOC濃度は経時的

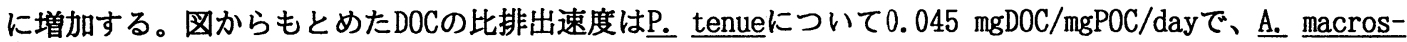
poraについては0.024mgDOC/mgPOC/dayとして . tenueの方が ことが分かる。次にDOC中の全糖類や蛋白 Table 5 Results under Dark Condition 質の経時変化に注目すると、 $\underline{\text { P. tenueにつ }}$ いて全糖類は暗培養初期には若干減少した 後、増加するが、タンパク質はほぼ同じレ ベルを維持する。一定期間培養したときの DOC量をTOC量で割ってDOCの排出率を求め ると暗培養23日目まではほぼ55\%前後であ るが、その以後には大きく增加する。23日 前後は細胞数が減少し、Thomaの血球計数 盤では細胞数を数えない期間にあたり、藻 類の自己溶解が進み、溶存性有機物が増加 すると考えられる。‥ macrosporaのDOC中

\begin{tabular}{|c|c|c|c|}
\hline \multicolumn{2}{|c|}{ tested alga } & $\underline{\text { P. tenue }}$ & A. macrospora \\
\hline \multirow{2}{*}{$\begin{array}{c}\text { specific } \\
\text { excretion } \\
\text { rate }\end{array}$} & mgDOC/mgPOC/day & 0.045 & 0.024 \\
\cline { 2 - 4 } & mgDOC/mgChl. a/day & 4.5 & 1.72 \\
\hline \multirow{2}{*}{$\begin{array}{c}\text { apparent } \\
\text { excretion rate } \\
\text { (mgC/1/day) }\end{array}$} & carbohydrates & 0.031 & 0.034 \\
\cline { 2 - 4 } protein & 0.004 & 0.044 \\
\hline \multirow{2}{*}{$\begin{array}{c}\text { decreasing } \\
\text { rate }\end{array}$} & Cells & 0.13 & 0.094 \\
\cline { 2 - 5 }$\left(\right.$ day $\left.^{-1}\right)$ & Ch1.a & 0.016 & - \\
\cline { 2 - 5 } & SS & 0.019 & 0.027 \\
\hline
\end{tabular}
の全糖類、タンパク質の割合は暗培養初期には各々 $60 \% 、 25 \%$ であったが、その以後各々 $50 \% 、 30 \%$ とな る。このことからPOC濃度の減少に伴うDOC濃度の増加とともに全糖類や蛋白質の増加が起こり、藻体の自 己溶解過程では藻体を構成している物質は完全に分解されずに、ある程度全糖類、蛋白質のような生分解 性の高い形の溶存性物質として放出されることが示唆される。Table 5に暗条件下の実験結果をまとめる。

\section{4 考察}

明条件では、実験開始直後より植物プランクトンは盛んに増殖を繰り返し、対数増殖を示した後、安定 期に入る。Fig. 10に示すようにA. macrosporaおよびP. tenueの緗胞とCh1.aの間では高い相関が見られ た。細胞当たりのChl.aの含有量は年. macrosporaについては $2.24 \times 10^{-6} \mu \mathrm{g} / \mathrm{cell}$ で、年 tenueについては 


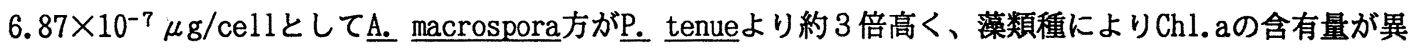
なることが分かる。

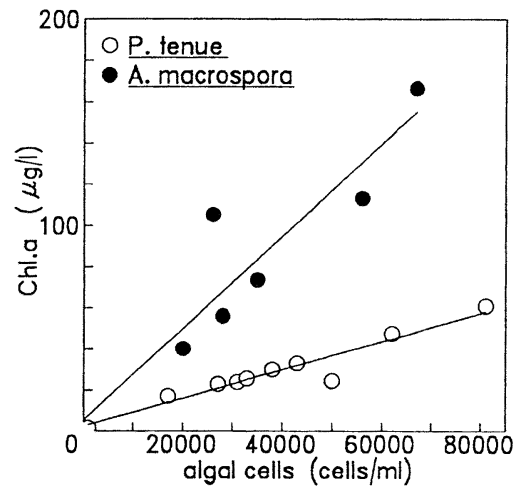

Fig. 10 Relationship between algal cells and Chl.a

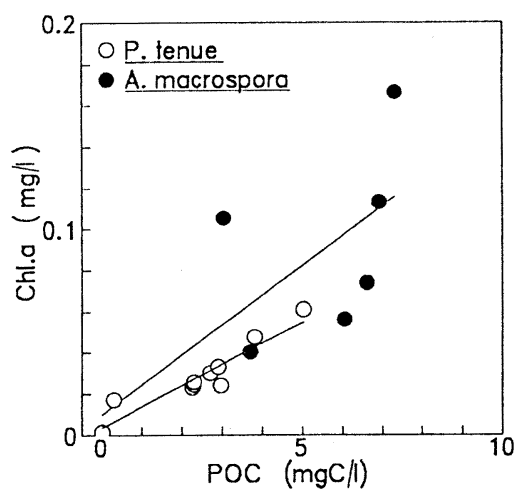

Fig. 11 Relationship between POC and Chl.a

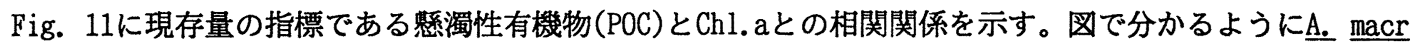
ospora とp. tenueとの間には若干の差が見られたものの、POCとChl.akは高い比例関係が認められ、各プ ロットが接する直線の傾きから、植 Table 6 Content of Chl.a in algae 物プランクトンのChl.a/POC比が A. macrosporaについては0.014であり、 P. tenueについては0.01であると考 えられる。Table 6に文献值を示すが、 これと比較しても本実験值ははほぼ 中間的な值となっている。しかしな がら、 A. macrosporaの安定期の細胞 のようにChl.aが減少するがPOCは増 加、あるいは暗条件初期のChl.aの増 大など、必ずしもCh1.aの含有率は一

\begin{tabular}{|c|c|c|c|c|}
\hline \multicolumn{2}{|c|}{ algal species } & & values & $\begin{array}{l}\text { No. of } \\
\text { reference }\end{array}$ \\
\hline \multirow{2}{*}{\multicolumn{2}{|c|}{$\begin{array}{l}\text { Chlorella sp. } \\
\text { Scenedesmus obliguus }\end{array}$}} & 0.012 & $\mathrm{mgChl} \cdot \mathrm{a} / \mathrm{mgdw}$ & 10 \\
\hline & & 0.021 & $\mathrm{mgChl} . \mathrm{a} / \mathrm{mgdw}$ & 11 \\
\hline \multirow{2}{*}{\multicolumn{2}{|c|}{$\begin{array}{l}\text { Chlorella sp. } \\
\text { S. capricornutum }\end{array}$}} & 0.0035 & $\mathrm{mgCh} 1 . \mathrm{a} / \mathrm{mgdw}$ & 12 \\
\hline & & 0.0048 & $\mathrm{mgCh} 1 . \mathrm{a} / \mathrm{mgdw}$ & 12 \\
\hline \multicolumn{2}{|c|}{ Stigeoclonium tenue } & 0.0040 & $\mathrm{mgCh} 1 . \mathrm{a} / \mathrm{mgdw}$ & 12 \\
\hline \multicolumn{2}{|c|}{ Chlamydomonas sp. } & 0.0033 & $\mathrm{mgCh} 1 . \mathrm{a} / \mathrm{mgdw}$ & 12 \\
\hline \multicolumn{2}{|c|}{ Microcystis sp. } & 0.0105 & $\mathrm{mgCh} 1 . \mathrm{a} / \mathrm{mgdw}$ & 12 \\
\hline \multicolumn{2}{|c|}{ simulation } & 0.02 & $\mathrm{mgCh} 1 . \mathrm{a} / \mathrm{mgC}$ & 13 \\
\hline \multirow[t]{3}{*}{ this } & A. macrospora & \\
\hline & P. tenue & \multirow{2}{*}{\multicolumn{3}{|c|}{$\begin{array}{l}6.87 \times 10^{-7} \mu \mathrm{gCh} 1 . \mathrm{a} / \mathrm{cel} 1 \\
0.014 \mathrm{mgCh} 1 . \mathrm{a} / \mathrm{mgC}(\mathrm{POC})\end{array}$}} \\
\hline & A. macrospora & & & \\
\hline study & P. tenue & 0.010 & \multicolumn{2}{|c|}{ mgChl.a/mgC(POC) } \\
\hline
\end{tabular}
定といえず、この0.01〜0.014は平均的な考えられ、場合によっては変化するものと理解する必要がある。

暗培養の初期においてPOC成分の減少が見られたが、これは細胞内の炭水化物が無機化されたと考えられ る。暗培養初期の無機化速度を求めると单 tenueについては0.037mgTOC/mgPOC/dayで、先. macrosporaは0 .196mgTOC/mgPOC/dayと評価され、 A. macrosporaの方が約5倍高い。さらにこれら無菌状態の実験とバクテ リア共存時の実験 ${ }^{14)}$ とを比較すると最大細胞数が 1 桁小さいが、DOCの比排出速度は大きい。このことか ら藻類の增殖および溶存性有機物の排出にバクテリアが大いに関与する可能性が示唆される。明条件の安 定期以後の比排出速度と暗条件での比排出速度の差を取って光合成過程におけるDOCの比排出速度を求める と0.020 mgDOC/mgPOC/dayと解析された。

\section{4. まとめ}

本実験では、琵琶湖疏水から単離した年. macrosporaおよびP. tenueを無菌的に培養し、藻類代謝産物の 生成パターンや組成特性を検討した。その結果を以下に要約する。

(1)明条件下での代謝産物の比排出速度は安定期の方が対数増殖期より約 2 7倍高く、対数増殖期以後の 代謝産物中の全糖類の割合は45～60\%で、蛋白質の割合は5～25\%程度であった。代謝産物の組成が藻類種 や増殖相により異なることが分かった。 
(2)暗条件下での減少速度は細胞数として0.094 0.13 $\mathrm{day}^{-1}$ (10底) であり、藻類の自己溶解による代謝 産物の比排出速度はP. tenueについては0.045、告. macrosporaについては0.024 mgDOC/mgPOC/dayとなった。

(3)光合成による代謝産物の比排出速度は $0.020 \mathrm{mgDOC} / \mathrm{mgPOC} /$ dayである。

(4)POC当りのChl.aの含有量は $0.01 \sim 0.14 \mathrm{mgChl} . \mathrm{a} / \mathrm{mgPOCの}$ 範囲にあった。

なお、P. tenueや‥ macrosporaは京都市水道局水質試験所から御厚意により譲り受けたことを記し、感 謝の意を現わします。

\section{参考文献}

1)宝月欣二(1976): 微生物の生態 3 増殖をめぐって 一微小藻類の異常増殖一、東京大学出版会

2)Keating, K. I. (1977):Allelopathic influence on blue green bloom sequence in a eutrophic lake , Science, 196, pp885 886

3)H. W. Kroes(1972): Growth interactions between Chlamydomonas globosa snow and Chlorococcum ellipsoideum deason and bold - The role of extracellular products -, Limnology and 0ceanography , 17, (3), pp423 432

4)李義信、宗宮功、藤井滋穂ら:土木学会第45回年次学術講演会、pp932～933、1990

5)Hellebust, J. A. (1965): Excretion of some organic compounds by marine phytoplankton, Limnology and Oceangraphy, 10, pp192 206

6)Sharp, J. H. (1977): Excretion of organic matter by marine phytoplankton- Do healthy cells do it? -, Limnology and Oceangraphy, 22, pp381 399

7)福島博、相沢貴子、真柄泰基(1981)：藻類によるトリハロメタン前駆物質の生成、水質污濁研究、第 4 巻、第 5 号、pp229 235

8)Richard, B. C. (1989): Bacterial uptake of dissolved free and combined amino acids in estuarine waters, Limnology and 0ceangraphy, 34(3), pp531 542

9)Wayne, H. B. (1983): Bacterial utilization of algal extracellular products - 3. The specificity of algal - bacterial interaction -, Limnology and Oceangraphy, 28(6), pp1131 1143

10)津野洋、合田健(1976):クロレラ種の増殖過程における窒素および燐濃度の影響に関する研究、環境問 題シンポ、Vol. 4、pp74〜 79

11)津田松苗(164):污水生物学、p230、北隆館

12)田井慎吾(1978):技術的評価一配水規制・処理効率の立場から一、新しい生物学的処理技術総覧、化学 技術開発センター、 pp59〜 74

13)DiToro, D. M., O' Connor, D. J. \& Thomann, R. V. (1971):A dynamic model for the phytoplankton population in the Sacramento - San Joaquin Delta -, Advances in Chemistry, No. 106, PP131 1 80

14)李義信、宗宫功、藤井滋穂(1992)：Water Research，投稿中 


\title{
(14) 接触材反応槽の付着微生物による河川水の浄化
}

\author{
PURIFICATION OF RIVER WATER BY ATTACHED \\ MICROORGANISMS IN THE REACTOR WITH \\ CONTACT MEDIA
}

\author{
海藤 剛* 相沢治郎* 海田輝之* 大村達夫* \\ Takeshi KAITOH*, Jiro AIZAWA*, Teruyuki UMITA*, Tatsuo OMURA*
}

\begin{abstract}
A B S TRACT ; Charcoal adsorbed $1.1 \mathrm{mgNH}_{4}-\mathrm{N} / \mathrm{kg}$, and did not adsorb $\mathrm{NO}_{2}-\mathrm{N}$ and $\mathrm{PO}_{4}-\mathrm{P}$. Oyster shell dissolved $12.22 \mathrm{mgPO}_{4}-\mathrm{P} / \mathrm{kg}$ in ten days, and did not adsorb $\mathrm{NH}_{4}-\mathrm{N}, \mathrm{NO}_{2}-\mathrm{N}$ and $\mathrm{NO}_{3}-\mathrm{N}$. The dissolution rate of $\mathrm{PO}_{4}-\mathrm{P}$ was decreased with time. Continuous purification of river water polluted slightly was studied with the use of reactors packed with charcoal and oyster shell on which microorganisms attached. At hydraulic retention times of 1 and 2 hours, TOC removal was over $50 \%$ in both reactors. Over $60 \%$ of $\mathrm{NH}_{4}-\mathrm{N}$ was converted due to the nitrification and the assimilation by attached microorganisms. However, removal of nitrogen was not almost observed. $\mathrm{PO}_{4}-\mathrm{P}$ removal was $10.2-86.7 \%$ at water tempertures of 15 and $8^{\circ} \mathrm{C}$, depending upon the composition of the substrate. It could be expected that these reactors contribute to the decrease of $\mathrm{PO}_{4}-\mathrm{P}$ loading into a reservoir in order to protect it from eutrophication.
\end{abstract}

KEYWORDS ; Purification by attached microorganisms, Contact media, River water, Phosphorus removal, Nitrogen removal

\section{1・はじめに}

我が国では、河川の大半は中小河川であり、将来の水資源の確保の観点から、このような中小河川に眝水夕 ムが建設されるようなってきている。これらの问川の流域内には、中規模都市や新規住宅地が存在している場 合が多く、眝水ダムの水質を悪化させる原因となり、宅地化が進んでいない場合でも、農地あるいは観光地等 からの污濁物質が、ダムに流入する可能性があり、中小河川の水質管理が重要になってきている。

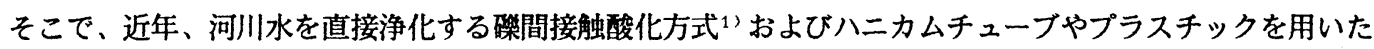
接触曝気方式が考えられてきている22，3，4)。しかしながら、これらの方式ではBOD, リン, 窒素等の濃度がか なり高い都市河川水等に適用されており、タムの水源となる比較的污澤の低い河川水に適用されてはいない。 また、これらの施設は多量の接触材が必要であり、多大な費用がかかる。そこで本研究では夕ムの水源となる ような、比較的污濁の少ない中小河川水の浄化を目的とし、接触材として、土地固有の産物である木炭と力キ 敖を用いて、このような河川水の浄化、すなわち有機物 (TOC), 窒素, リンの除去特性について検討を行った。

* 岩手大学工学部建設㻴境工学科 Department of Civil and Environmental Engineering, Iwate Univ. 